\title{
Performances of Jatropha and Waste Cooking Oil Biodiesel Blends Fuel Combustion using Diesel Engine
}

\author{
A. R. Norwazan*, N. Norzaima, M. R. A. Rahman, M. S. R. Nasir \\ Department of Mechanical Engineering, Faculty of Engineering, \\ Universiti Pertahanan Nasional Malaysia, Kem Sg. Besi, 57000, Kuala Lumpur, MALAYSIA \\ *Corresponding Author
}

DOI: https://doi.org/10.30880/ijie.2020.12.05.016

Received 21 May 2020; Accepted 28 May 2020; Available online 30 June 2020

\begin{abstract}
High demands on biodiesel fuel usage on diesel engine is influences the manufacturer to produce more biodiesel fuel especially by using waste products instead of plant oil. Currently, waste products are easily to recycle in many ways including fuel production in order to get better environment. In addition, biodiesel fuel consuming is claimed in $\mathrm{HC}$ and $\mathrm{CO}$ emissions reduction. It shows that biodiesel fuel combustion is promising to emit the green emissions into environment and protect our planet from global warming. Biodiesel fuel consumption also is one of an alternative to support high demand and depleting of fossil fuel. Jatropha oil and waste cooking oil biodiesel fuels were produced using a two-step of transesterification process using methanol with sulfuric acid catalyst to diminish their free fatty acid level. Then, the transesterification was continued with methanol and the catalyst of potassium hydroxide. The paper focuses on the determination of chemical properties of biodiesel blends fuel using jatropha oil and waste cooking oil biodiesel fuel in different percentages. It also presents the combustion performances and emissions of both biodiesel fuels in diesel engine.
\end{abstract}

Keywords: Waste cooking oil biodiesel, combustion, emissions, internal combustion engine

\section{Introduction}

In the modern world development, biodiesel is the one of the clean fuel and be alternative in the many heavy industries and transportation sector. Biodiesel can be defined as a renewable fuel that produces from plant oils and animal fats by using transesterification, micro-emulsions or pyrolysis methods. The demands for biodiesel are increasing from year to year due to depleting of fossil fuel. The use of biodiesel fuel can be reduced the emissions of $\mathrm{NO}_{\mathrm{x}}$ and $\mathrm{CO}$ that can affect human health such as coughing and reduction of immunity to lung infections [1]. Plant oil extracted from palm, castor, jatropha, sunflower, rapeseed and rubber seed amongst the famous trend used as an alternative resource to produce biodiesel fuel due to effectiveness of consuming this oil due to availability in the market. Currently, waste cooking oil (WCO) is highly recommended as a medium to produce biodiesel fuel since it is considered as waste products. WCO also considered as low-cost raw material and easily to collect. Conversion this waste product to biodiesel can be as alternative to solve the waste disposal problem into environment [2]. Meanwhile, jatropha oil (JO) biodiesel is initiated by Indian government and become as main biodiesel product due to its yield of oil content and easily to cultivate [3]. It also has good and desirable properties like low acidity, low viscosity and good stability compared to palm and castor oils [4].

The mixing of WCO biodiesel fuel and Butylated hydroxytoluene (BHT) with the additive of n-butanol was tested by using a four stroke, air-cooled diesel engine. The emission of biodiesel fuels was observed for blends of B0, B20, B30, B40 and B100. The studies showed that B30 was optimum blend compared to other biodiesel blends fuel on the thermal efficiency, rate of heat release, and their emission of $\mathrm{HC}, \mathrm{CO}$ and $\mathrm{CO}$ results [5]. In other studies, the results showed that B20 and B5 biodiesel blends fuel from WCO gave better emission results. Diesel fuel was compared to B5 and $\mathrm{B} 20$ produced significant reductions of $\mathrm{CO}$ and $\mathrm{HC}[6]$. 
Dhakad were tested the blends of B0, B10, B20, B30. B40 and B50 of JO biodiesel using internal combustion engine under variable load conditions [7]. It found that B30 of JO biodiesel has higher performance and recommended for internal combustion engine. B20 of JO biodiesel combustion found has lower $\mathrm{CO}$ and NOx emissions even increasing load in water-cooled diesel engine [8]. Kathirvelu found that B100 of JO methyl ester showed that the higher emission of NOx compared to the B20 of JO methyl ester at $2.2 \mathrm{~kW}$ of brake power [9]. In the research of internal combustion engine showed that the results of B75 JO methyl ester were produced the most emission of NOx compared with B25 and B50 at engine speed of $1800 \mathrm{rpm}$ [10]. It also showed that the average NOx emissions with B25, B50 and B75 were increased of $12 \%, 15 \%$ and $18 \%$ at all the conditions of operating. In single cylinder DI engine testing, it showed that the brake power and engine torque were reduced by JOME compared to diesel fuel combustion significantly [11]. Paul reported that $\mathrm{JO}$ has higher density, flash point, viscosity and cetane number than those of diesel engine [12].

The B10, B20 and B30 of WCO biodiesel blends fuel had been used in internal combustion engine [13] It showed that the reduction of brake thermal efficiency when concentration of WCO increased. Meanwhile, the nearest result to the brake thermal efficiency of diesel fuel was B10. The result also showed that the increasing of specific fuel consumption as the blend percentage increased. Yildizhan was tested WCO blends fuel in variable compression ratio engine found that the $\mathrm{CO}$ emissions improved by compression ratio increased [14]. B20 has improved up to $21.75 \%$ compared to all WCO blends and diesel. The results of WCO biodiesel combustion showed that the increasing of blend percentage caused the NOx emission to be increased. At $80 \%$ of engine load, the highest fuel blend for NOx emission was B80 [15]. Meanwhile, the lowest emission of NOx was B20. The different for NOx emission can be related to their oxygen contents in the fuel blend. The oxygen contain in B80 was higher compared to the B20. Thus, the B80 emission for NOx was higher than B20.

The purpose of this study was to evaluate the characteristics of JO and WCO biodiesel blends in various percentages with diesel fuel and combustion performances on internal combustion engine. The potential use of JO and WCO biodiesel blends in diesel engine can thus be determined and assessed from this study

\section{Material and Method}

The first step in the production of biodiesel from waste cooking oil was the esterification process. But the waste cooking oil must be filtered and boiled to remove the moisture. The $300 \mathrm{~mL}$ of waste cooking oil was heated in a threeneck flask $(500 \mathrm{~mL})$ to $65^{\circ} \mathrm{C}$. Then, the molar ratio at $12: 1(50 \% \mathrm{v} / \mathrm{v}$ oil $)$ of methanol was measured and added into the pre-heated oil followed by $1 \%\left(\mathrm{~m} / \mathrm{m}\right.$ oil) of $\mathrm{H}_{2} \mathrm{SO}_{4}$. This process used a thermometer, mechanical stirrer and reflux condenser to condense the methanol escaping from the reaction mixture, using $400 \mathrm{rpm}$ stirring speed for 2 hours at $65^{\circ} \mathrm{C}$. After the esterification process was completed, the reaction oil was poured into a separation funnel for 2 hours to separate the oil and excess alcohol with $\mathrm{H}_{2} \mathrm{SO}_{4}$. The lower layers of waste cooking oil biodiesel were put into a three-neck flask and the acid value was found to be less than $3 \mathrm{mg} \mathrm{KOH} / \mathrm{g}$ oil.

After completion of the esterification process, the most common method to complete the production of biodiesel is by a homogeneous transesterification process. The triglyceride obtained from the initial esterification process was reacted with $25 \%$ (v/v oil) methanol (or $6: 1$ molar ratio) and $1 \mathrm{wt} \%\left(\mathrm{~m} / \mathrm{m}\right.$ oil) catalyst of $\mathrm{KOH}$ at $60^{\circ} \mathrm{C}$. The triglyceride, alcohols and catalyst of $\mathrm{KOH}$ were reacted in the same equipment used in the previous process under reflux for 2 hours and 400 rpm stirring speed. Then, the products were poured in separation funnel up to 12 hours to separate the biodiesel and glycerol. The glycerol with impurities that made up the bottom layer was drawn off.

The methyl esters formed in the transesterification process continued into the post-treatment of washing it with warm $\left(50^{\circ} \mathrm{C}\right)$ distilled water five times to remove the excess alcohol, catalyst and remained glycerol. The ratio of distilled water to biodiesel was 2:1. The process continued with heated of the liquid up to $110^{\circ} \mathrm{C}$ and stirring of the methyl ester into the Erlenmeyer flask to remove the moisture and remaining methanol. Finally, the WCO biodiesel fuel was filtered in room temperature using funnel and filtered paper. Then, WCO biodiesel fuel was stored in an airtight bottle.

JO and WCO biodiesel blends fuels were prepared by using blending process with certain percentages accordingly. Mixing of diesel and JO or WCO biodiesel fuels are started with measurement of specific gravity and volume appropriately. Then, the blending process is occurring until the blend fuel become homogeneously. The blend percentages of both biodiesel fuels are including B15, B25 and B50. Biodiesel has physical and chemical properties that are different from diesel fuel, depending on the type of monoalkyl ester. These properties must be investigated using standard testing according to ASTM 6751 or EN 14214 standards. The characterizations of WCO biodiesel fuel properties have been done according to ASTM standard as mentioned in Table 1.

The characterization of blend will be determined by obtaining their density, kinematic viscosity, and flash point. Each blend will have a different value of characterization. Thus, each blend needs to be compared to evaluate their performances. Waste cooking oil biodiesel fuel blends were tested to evaluate their engine performance test by using engine test bench model TMT400 with Lombardini Diesel Engine. There were four combustion characteristics and performances to be achieved in this experiment including brake power, torque value, NOx and CO emissions. 
Table 1 - Physical-chemical properties of diesel, WCO and JO blends fuel

\begin{tabular}{|c|c|c|c|c|c|c|c|c|c|c|}
\hline Parameter & Diesel & $\begin{array}{l}\text { WCO } \\
\text { B15 }\end{array}$ & $\begin{array}{l}\text { WCO } \\
\text { B25 }\end{array}$ & $\begin{array}{l}\text { WCO } \\
\text { B50 }\end{array}$ & $\begin{array}{l}\text { WCO } \\
\text { B100 }\end{array}$ & $\begin{array}{l}\text { JO } \\
\text { B15 }\end{array}$ & $\begin{array}{l}\text { JO } \\
\text { B25 }\end{array}$ & $\begin{array}{l}\text { JO } \\
\text { B50 }\end{array}$ & $\begin{array}{l}\text { JO } \\
\text { B100 }\end{array}$ & Standard \\
\hline Density $\left(\mathrm{g} / \mathrm{m}^{3}\right)$ & 0.835 & 0.8494 & 0.8518 & 0.8611 & 0.877 & 0.8501 & 0.853 & 0.8627 & 0.8821 & $\begin{array}{l}\text { ASTM } \\
\text { D4052 }\end{array}$ \\
\hline $\begin{array}{l}\text { Kinematic } \\
\text { viscosity } \\
\left(\mathrm{mm}^{2} / \mathbf{s}\right)\end{array}$ & $3.619^{*}$ & 3.2407 & 3.3255 & 3.7099 & 4.579 & 3.2757 & 3.3425 & 3.7191 & 4.495 & $\begin{array}{l}\text { ASTM } \\
\text { D445 }\end{array}$ \\
\hline $\begin{array}{l}\text { Flash point } \\
\left({ }^{\circ} \mathrm{C}\right)\end{array}$ & $60 * *$ & 79 & 80 & 88 & 186 & 84 & 85 & 91 & 187 & $\begin{array}{l}\text { ASTM } \\
\text { D93 }\end{array}$ \\
\hline
\end{tabular}

Refer to *Abedin et al. (2014) **Ng \& Gan (2010)

\section{Experimental Work}

Fig. 1 illustrates the schematic diagram of experimental set up to test the performance and emission characteristics of biodiesel blends fuel. A direct injection of 1 cylinder and 4 stroke air cooled diesel engine attached by dynamometer with digital data acquisition system. Biodiesel blend fuel has been filled into the fuel tank accordingly. To begin with, the engine was started and run in 20 minutes till the engine stabilized. The experimental work is beginning with diesel fuel test, then followed by WCO and JO biodiesel blends fuel. The test was started with speed of $1000 \mathrm{rev} / \mathrm{min}$ till 2200 $\mathrm{rev} / \mathrm{min}$ for each blend. Every changes of speed, the engine needs $15 \mathrm{mins}$ to stabilize it before data reading. Electronic gas analyzer, Drager EM200 was used to measure the formation of emission gaseous such as NOx. The emission probe was inserted into the exhaust of engine to measure the emissions formation. To get accuracy and reliability of measurement, the experimental was carried out up to three times.

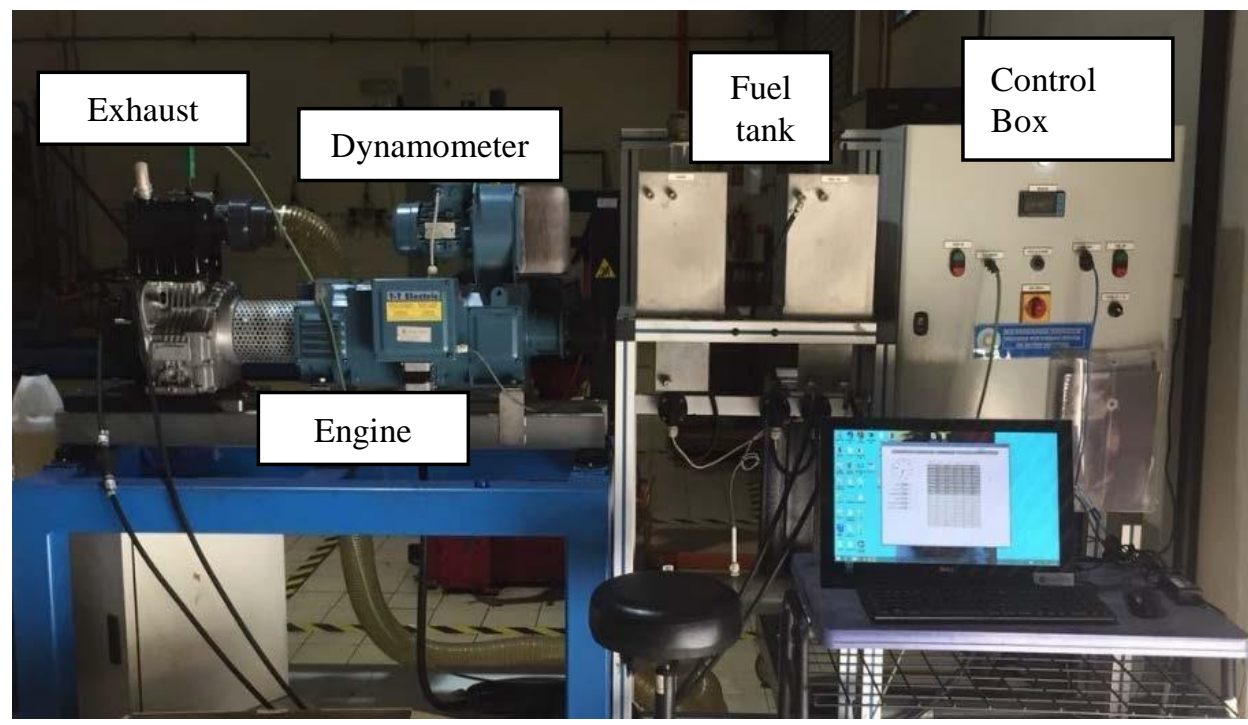

Fig. 1 - Schematic diagram of test setup

Table 2 - Specification of internal combustion engine test bench

\begin{tabular}{cc}
\hline Specification & Details of TMT 400 \\
\hline Model & Diesel Engine Lombardini \\
\hline Bore X Stroke $(\mathbf{m m})$ & 82 X 66 \\
\hline Number of Cylinder & 1 \\
\hline Injection system & DI \\
\hline Cycle & 4 strokes \\
\hline Volume of fuel tank & $20 \mathrm{~L}$ \\
\hline Cooling system & Air cooled \\
\hline
\end{tabular}

\section{Results and Discussion}

Performance of engine was determined by using the TMT400 software that connected to internal combustion engine test rig. In this study, the combustion performances focused on brake torque and brake power only. The results of each biodiesel blend fuel were tested and compared accordingly for every increment of $100 \mathrm{rpm}$ of engine speed. At $1400 \mathrm{rpm}$, 
the engine was reached the economic condition where it showed that all the data in the same trend. Then, the combustion performance will be evaluated from $1400 \mathrm{rpm}$ to $2200 \mathrm{rpm}$. The graph might to be a non-linear because of the irregular condition of engine. From Fig. 2, it shows that WCO B15 had the highest value for torque compared with other blends. Then, followed by WCO B25 and WCO B50. It can be seen that lowest percentages of WCO gives the highest torque with increment of engine speed. Roskilly found that almost no loss of torque for the whole test range of WCO blends fuel for $30 \%, 70 \%$ and $100 \%$ [16].

Meanwhile, JO biodiesel blends fuel presented lower torque compared to WCO blends. As highest as JO blend percentages, the torque obtained lower. The reduction of torque with blends can be related to lower heating value of fuels. A study by Nursal, the torque values of JO biodiesel fuel for B5 and B10 were $4 \mathrm{Nm}$ and $3 \mathrm{Nm}$ respectively [17]. In this experiment results showed that the values of JO B15, JO B25, and JO B50 were $5.9 \mathrm{Nm}, 5.8 \mathrm{Nm}$, and 5.7 Nm respectively. Sanggeta mentioned that the JO biodiesel used in diesel engine decreased torque, brake power and brake thermal efficiency [18]. Based on all the results, it was shown that the torque values decreased as the fuel blends increased. This is related to blends fuel contain lower heating value when increasing their blend percentages.

Based on Fig. 3, the brake power varied from $1000 \mathrm{rpm}$ to $2200 \mathrm{rpm}$ of engine speed for all biodiesel blends fuel. In average the results showed that the brake power of WCO blends fuel increased as the blend percentages decreased. Starting with WCO B15, followed by WCO B25 and WCO B50, the brake power was decreased. It may cause by the lower heating values of the WCO blend.
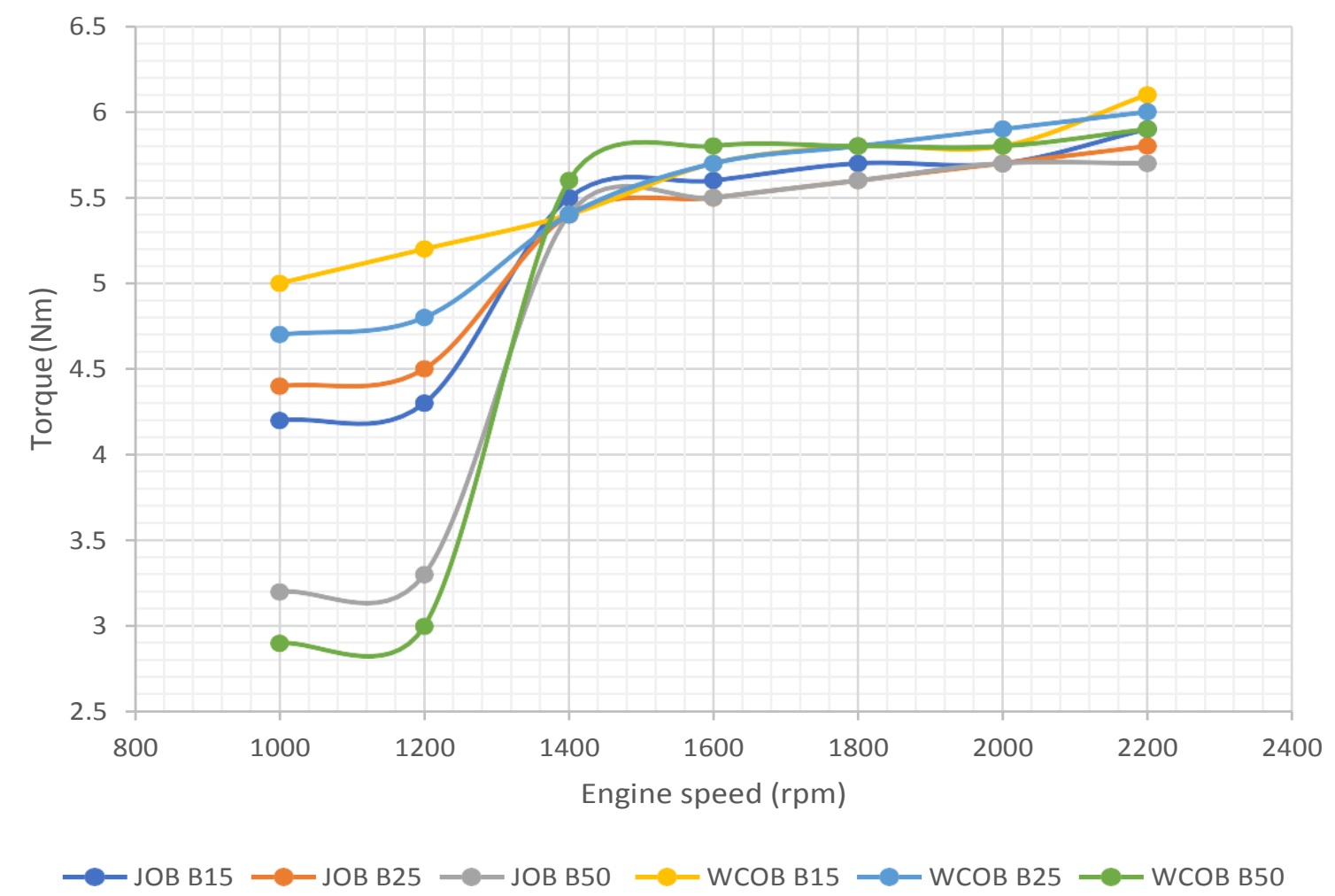

Fig. 2 - Comparison of torque against engine power in different biodiesel blends fuel

In this experiment showed WCO B15 as the value of brake power was $1.36 \mathrm{~kW}$. Meanwhile, WCO B25 and WCO $\mathrm{B} 50$ produced brake power of $1.34 \mathrm{~kW}$ and $1.31 \mathrm{~kW}$ respectively. Nursal mentioned that WCO biodiesel blends fuel of $\mathrm{B} 5$ and B10 were $0.30 \mathrm{~kW}$ and $0.25 \mathrm{~kW}$ respectively [17]. In the present study, the values of brake power for B15, B25, and $\mathrm{B} 50$ were $1.41 \mathrm{~kW}, 1.38 \mathrm{~kW}$, and $1.36 \mathrm{~kW}$. Based on all the results, it shown that the brake power decreased as the fuel blends increased. This is because of their lower heating values when they produced lower brake power.

The combustion performances of JO biodiesel blends fuel are showed that the brake power also decreased as blend percentages increased. JO biodiesel blends were performed lower that WCO biodiesel blends. Liaquat found that JO biodiesel fuel produced values of brake power for B5 and B10 were $3.25 \mathrm{~kW}$ and $3.10 \mathrm{~kW}$ [19]. Contrary with Nursal studies, it found that JO biodiesel blend fuels were presented higher brake power than WCO biodiesel blends in diesel engine. 


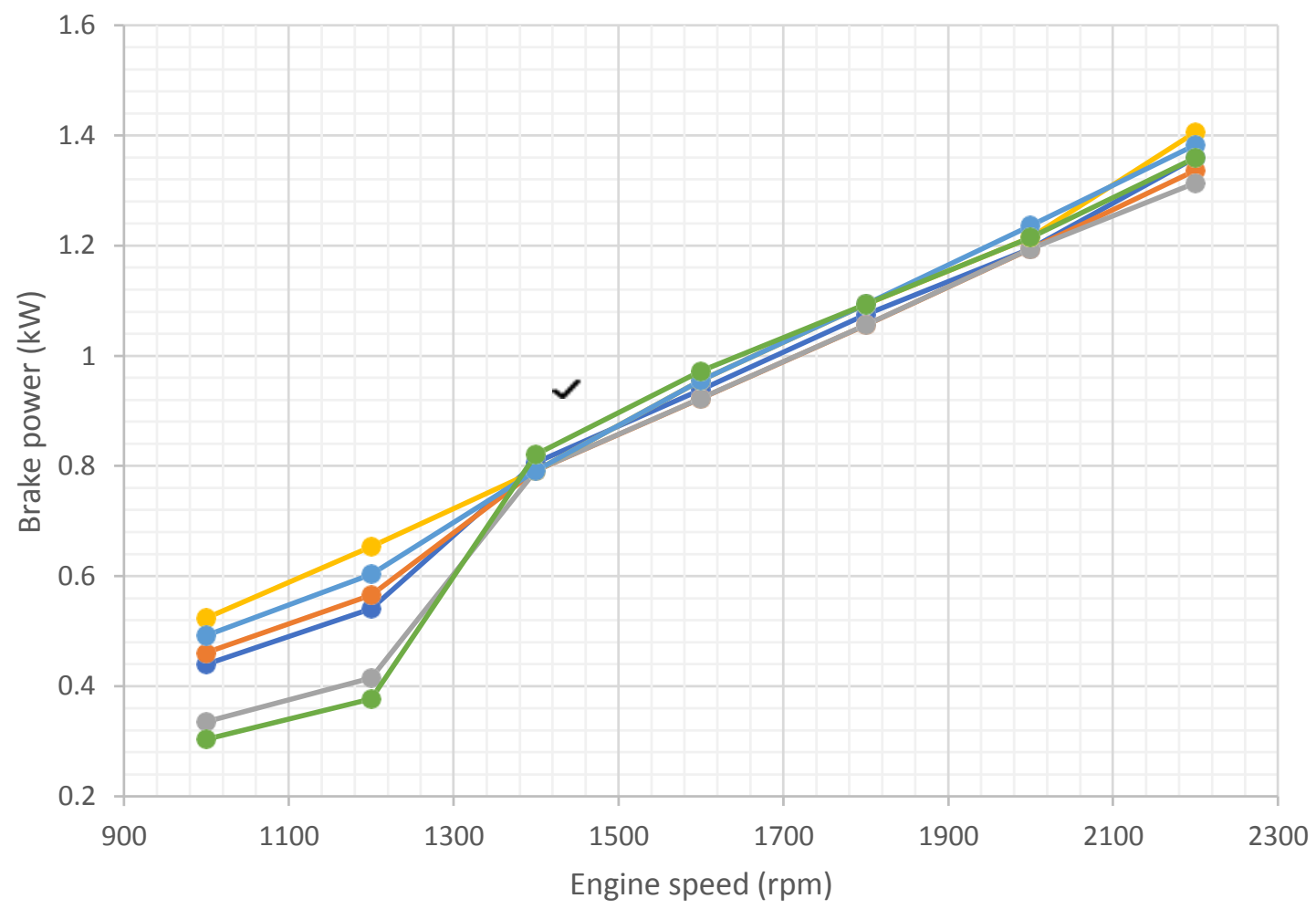

$\longrightarrow$ - JOB B15 - - JOB B25 - JOB B50 - WCOB B15 $\multimap$ WCOB B25 - WCOB B50

Fig. 3 - Comparison of brake power against engine power in different biodiesel blends fuel

Emissions of NOx of JO biodiesel fuels were lower compared to the WCO biodiesel fuel for each blend. NOx value of JO B15 and WCO B15 were 76 ppm and 80 ppm. When blend percentages increased, NOx emissions of JO B25 and WCO B25 biodiesel blends fuel were increasing to $77 \mathrm{ppm}$ and $81 \mathrm{ppm}$ respectively. Meanwhile, NOx emission of B50 for JO and WCO biodiesel fuels were obtained 94 ppm and 98 ppm. For both biodiesel, the NOx emissions are higher in higher blend percentage of B50 due to higher content of oxygen in the biodiesel. As higher as oxygen in biodiesel gives higher flame temperature during combustion. Thus, it produced higher NOx emissions as well. Liaquat obtained that the values of NOx emissions of B5 and B10 JO were $410 \mathrm{ppm}$ and $425 \mathrm{ppm}$. Meanwhile, Nursal found that the values of NOx were 24 ppm and 28 ppm in small diesel engine. Studies of WCO biodiesel blends fuel of B25 and B50 in 4 stroke turbo DI engine were produced NOx emissions at $1110 \mathrm{ppm}$, and $1125 \mathrm{ppm}$ respectively [10]. The formations of NOx are strongly dependent on their oxygen content. The oxygen in the blend fuels can react with nitrogen easily during the process of combustion. Based on Fig. 3, the graph shows that both biodiesel fuels were increasing in NOx emissions as the biodiesel blends fuel increased. However, WCO biodiesel fuel was higher in their emissions of NOx compared to the emissions of JO biodiesel fuel.

$\mathrm{CO}$ is the intermediate product of combustion. It is formed due to incomplete fuel combustion. The complete combustion will convert the $\mathrm{CO}$ into $\mathrm{CO}_{2}$. The $\mathrm{CO}$ will be formed during incomplete combustion due to lack of air. In fuel blends, the emissions will be lower because the molecules of fuel blends have extra oxygen that result in complete combustion. It will supply necessary oxygen to convert from $\mathrm{CO}$ into $\mathrm{CO}_{2}$. Based on Fig. 4, it was shown that both $\mathrm{CO}$ emission of JO and WCO biodiesel blends fuel were decreased from B15 to B50. However, the JO biodiesel blends fuel had lower emissions of CO compared to the WCO biodiesel blends fuel.

In overall, WCO biodiesel blends fuel are produced higher of $\mathrm{CO}$ emissions compared to JO biodiesel blends fuel. CO emissions from JO B15 and WCO B15 biodiesel were 1034 ppm and 1546 respectively. For B25 of JO and WCO biodiesel blends fuel were $991 \mathrm{ppm}$ and $1307 \mathrm{ppm}$. Meanwhile, the emission of CO of JO B50 and WCO B50 were 950 ppm and $1121 \mathrm{ppm}$. Nursal obtained that CO emissions of JO B10 and B15 were 190 ppm and 65 ppm. Shirneshan reported that $\mathrm{CO}$ emission was reduced in $18.75 \%$ from WCO biodiesel experimental testing using four stroke turbocharged DI engine. CO emissions from biodiesel combustion were reduced due to higher oxygen content [20]. Higher blend percentages lead better CO emissions. A different type of engine also affects the CO emissions [16]. 


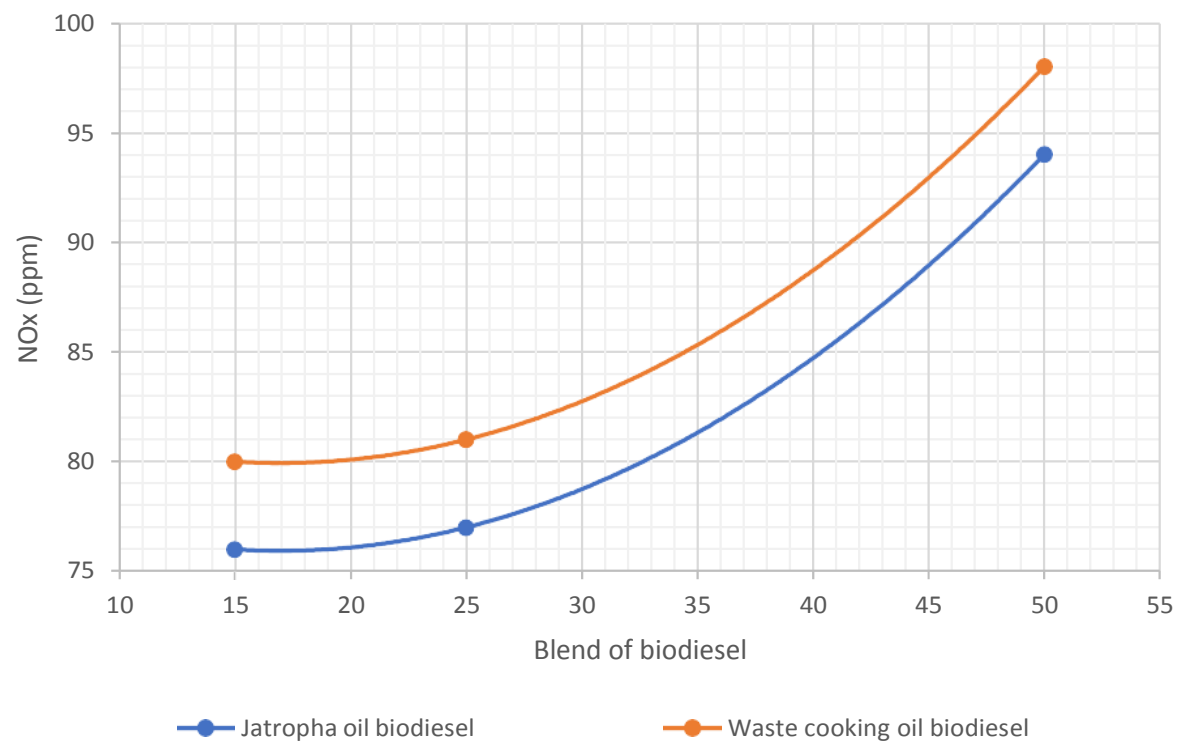

Fig. 4 - NOx emissions of jatropha oil and waste cooking oil biodiesel blends fuel

\section{Conclusion}

In this study, JO and WCO biodiesel blends fuel were performed in single cylinder turbocharged diesel engine. Both biodiesel fuels were esterified via homogeneous transesterification method and have been blended with diesel fuel to form B15, B25 and B50. Their properties were characterized properly to meet biodiesel ASTM standard. JO biodiesel has higher density and flash point but lower viscosity compared to WCO biodiesel fuel and their blends. Combustion performances of both biodiesels were observed on engine torque and brake power significantly. Therefore, NOx and CO emissions are analyzed properly to compare for each blend percentages. It is showed that by increasing the blend percentages of biodiesel will be caused the increment of oxygen content. Then, the blends are combusted completely and produced less CO emission. Meanwhile, NOx emissions were increased with the increment of biodiesel blends for both JO and WCO biodiesel.

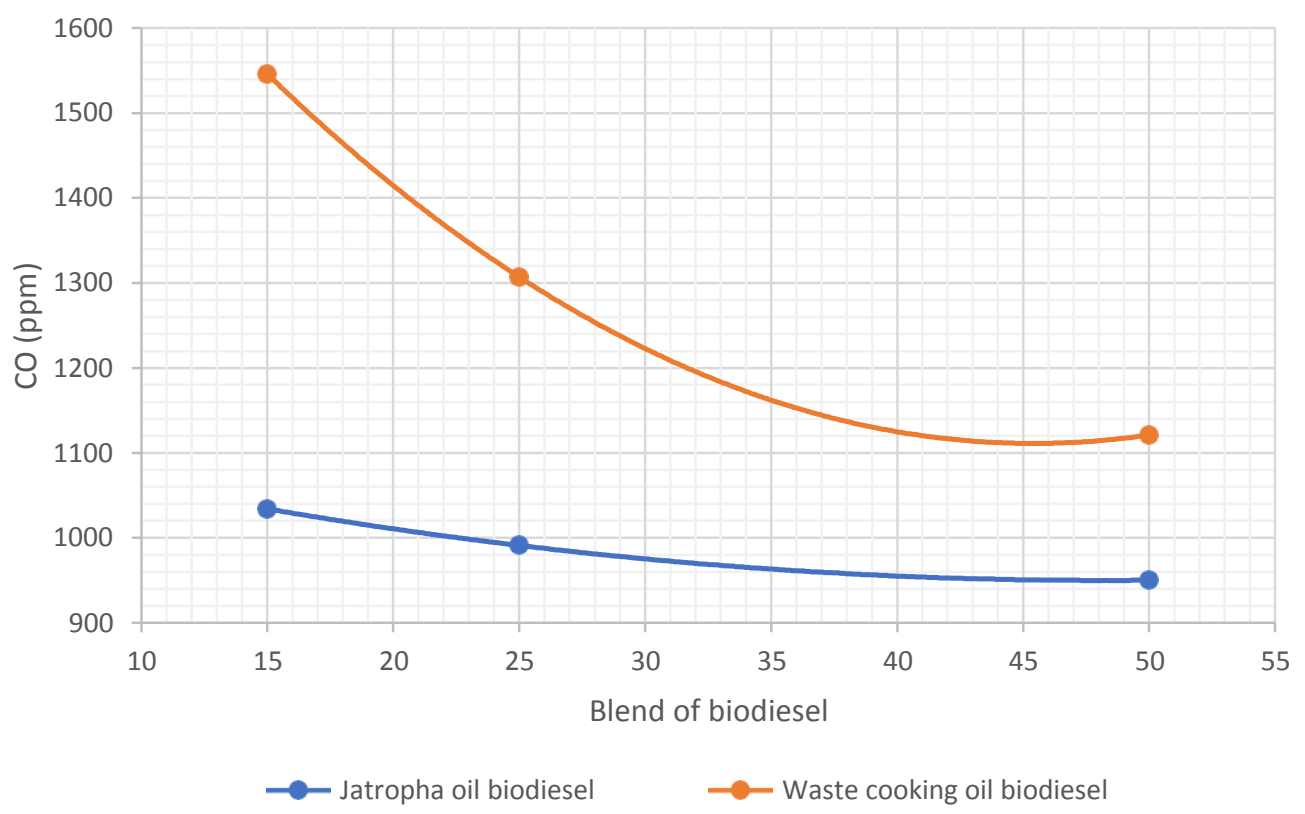

Fig. 5 - CO emissions of jatropha oil and waste cooking oil biodiesel blends fuel 


\section{Acknowledgement}

The authors would like to thankful to Universiti Pertahanan Nasional Malaysia (UPNM) for their funding under Go Green Internal Grant J0112 (Lt Cdr. Norzaima Nordin, Project Leader).

\section{References}

[1] Bhuiya, M. M. K., Rasul, M. G., Khan, M. M. K., Ashwath, N., and Azad, A. K. (2016). Prospects of 2nd generation biodiesel as a sustainable fuel-Part: 1 selection of feedstocks, oil extraction techniques and conversion technologies. Renewable and Sustainable Energy Reviews, 55, 1109-1128.

[2] Zareh, P., Zare, A.A., Ghobadian, B. (2017). Comparative assessment of performance and emission characteristics of castor, coconut and waste cooking based biodiesel as fuel in a diesel engine, Energy, 139, 883-894.

[3] Tamilselvan, P., Nallusamy, N. and Rajkumar, S. (2017). A comprehensive review on performance, combustion and emission characteristics of biodiesel fuelled diesel engines, Renewable and Sustainable Energy Reviews, 79, 11341159.

[4] Koh, M. Y. and Mohd. Ghazi, T. I. ( 2011). A review of biodiesel production from Jatropha curcas L. oil., Renewable and Sustainable Energy Reviews, 15(5), 2240-2251.

[5] Senthur Prabu, S., Asokan, M. A., Roy, R., Francis, S., and Sreelekh, M. K. (2017). Performance, combustion and emission characteristics of diesel engine fuelled with waste cooking oil bio-diesel/diesel blends with additives. Energy, 122, 638-648.

[6] Adaileh, W.M., \& Alqdah, K.S. (2012). Performance of diesel engine fuelled by a biodiesel extracted from a waste cocking oil. Energy Procedia, 18, 1317-1334.

[7] Dhakad, S., Parashar, U., Dandotiya, D., Dhakad, V., \& Gurjar, J. (2013). Practical Performance of Internal Combustion Engine Using Jatropha Oil as A Bio-Fuel, 3 (10), 4-7.

[8] Mamilla, V. R., Mallikarjun, M. V., \& Rao, G. L. N. (2013). Performance analysis of IC engines with bio-diesel jatropha methyl ester (JME) blends, Academic Journals, 4(5), 90-93.

[9] Kathirvelu, B., Subramanian, S., Govindan, N., \& Santhanam, S. (2017). Emission characteristics of biodiesel obtained from jatropha seeds and fish wastes in a diesel engine. Sustainable Environment Research, 27(6), 283-290.

[10] Arslan, R. (2011). Emission characteristics of a diesel engine using waste cooking oil as biodiesel fuel. African Journal of Biotechnology, 10 (19), 3790-3794.

[11] El-Kasaby M. and Nemit-allah M.A. (2013). Experimental investigations of ignition delay periodand performance of a diesel engine operated with Jatropha oil biodiesel. Alex Eng J 52:141-9.

[12] Paul G., Datta A., and Mandal B.K. (2014). An Experimental and Numerical Investigation of the Performance, Combustion and Emission Characteristics of a Diesel Engine fueled with Jatropha Biodiesel. Energy Procedia, 54, 455-67.

[13] Patel, M. J., Patel, T. M., \& Rathod, G. R. (2015). Performance Analyis of C.I. Engine Using Diesel and Waste Cooking Oil Blend. IOSR Journal of Mechanical and Civil Engineering, 12(2), 2320-334.

[14] Yildizhan, Ş., Uludamar, E., Çalık, A., Dede, G., \& Özcanlı, M. (2017). Fuel properties, performance and emission characterization of waste cooking oil (WCO) in a variable compression ratio (VCR) diesel engine. European Mechanical Science, 1(2), 56-62.

[15] Shirneshan A.A. (2013). HC, CO, CO2 and NOx Emission evaluation of a diesel engine fueled with waste frying oil methyl ester, Procedia - Social Behav Sci 75, 292-7.

[16] Roskilly A.P., Nanda S.K., Wang Y.D., and Chirkowski J. (2008). The performance and the gaseous emissions of two small marine craft diesel engines fuelled with biodiesel. Applied Thermal Engineering, 28, 872-80.

[17] Nursal, R.S., Khalid, A., Ahmad Syukri Ahmad Tajuddin, \& Hadi, S.A. (2016). Performance and emissions characteristics of alternative biodiesel fuel on small diesel engine, ARPN Journal of Engineering and Applied Science, Vol. 11, No. 12.

[18] Sangeeta Moka S, Pande M, Rani M, Gakhar R, Sharma M, et al. (2014). Alternative fuels: an overview of current trends and scope for future. Renew Sustain Energy Rev, 32, 697-712.

[19] Liaquat, A. M., Masjuki, H. H., Kalam, M. A., Varman, M., Hazrat, M. A., Shahabuddin, M., \& Mofijur, M. (2012). Application of blend fuels in a diesel engine. Energy Procedia, 14, 1124-1133.

[20] Jinlin Xue (2013). Combustion characteristics, engine performances and emissions of waste edible oil biodiesel in diesel engine. Renewable and Sustainable Energy Reviews, 23, 350-365. 